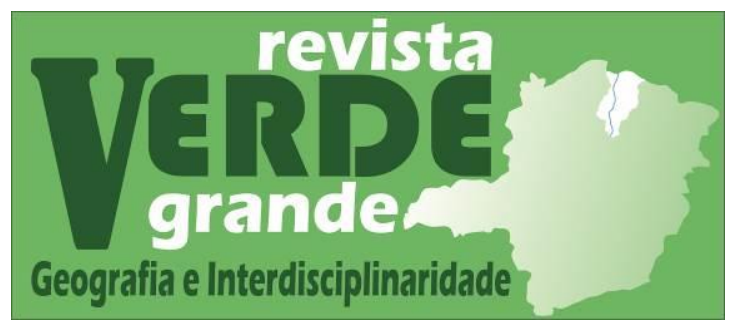

\title{
ASPECTOS GEOAMBIENTAIS DAS ÁREAS DE NASCENTES NO ALTO CURSO DA SUB-BACIA HIDROGRÁFICA DO RIO FIGUEIREDO/CEARÁ
}

\author{
Geo-environmental aspects of spring areas in the high hydrographic sub-basin course of the \\ Figueiredo river/Ceará
}

Diêgo Souza Albuquerque ${ }^{1}$ https://orcid.org/0000-0002-0504-4972

Maria Losângela Martins de Sousa² https://orcid.org/0000-0003-3798-283X

\footnotetext{
${ }^{1}$ Mestre em Planejamento e Dinâmicas Territoriais no Semiárido - Universidade do Estado do Rio Grande do Norte, Campus Avançado de Pau dos Ferros. E-mail: diealbuquerque07@gmail.com

${ }^{2}$ Doutora em Geografia. Professora do Departamento de Geografia - Universidade do Estado do Rio Grande do Norte, Campus Avançado de Pau dos Ferros. E-mail: losangelaufc@gamil.com
}

\begin{abstract}
Resumo
Os estudos destinados ao entendimento da dinâmica dos elementos (físicos e humanos) do ambiente são importantes para tomada de decisões sobre o uso dos resursos naturais. Nesse tocante, a compreensão do quadro físico e da ocupação humana de um dado espaço pode ser fundamental para a gestão daquele território. O presente estudo teve como objetivo principal fazer uma contextualização geoambiental das áreas de nascentes no alto curso da sub-bacia hidrográfica do rio Figueiredo, estado do Ceará. O trabalho foi realizado através de estudos bibliográficos, levantamentos geocartográficos, técnicas de geoprocessamento e trabalhos de campo. Obteve-se uma base de dados consistente para a realização da análise sistêmica mais profícua, com vista a identificar os sistemas ambientais. Constatase que a área em evidência apresenta uma rica diversidade paisagística, sendo essa proporcionada pelos seus atributos naturais. Quanto as atividades de ocupação, deflagram-se como potencializadoras da degradação ambiental. Desta feita, fica nítida a necessidade da adoção de práticas conservacionistas que proporcionem a sustentabilidade dos sistemas ambientais da área em foco.
\end{abstract}

Palavras-chave: Meio físico; Ocupação humana; Análise sistêmica.

\begin{abstract}
Studies aimed at understanding the dynamics of the elements (physical and human) of an environment are important for making decisions about the use of natural resources. In this regard, understanding the physical situation and the human occupation of a given space can be fundamental for the management of a territory. Thus, this study had as main objective to make a geoenvironmental contextualization of the spring areas of the high hydrographic sub-basin course of the Figueiredo river, Ceara state. For this, the work was carried out through bibliographic studies, geocartographic surveys, geoprocessing techniques and field work. A consistent database was obtained to carry out the systemic analysis, in order to identify the environmental systems. Finding out that the area in evidence presents a rich landscape diversity, which is provided by its natural attributes. As for occupation activities, they are triggered as potentializers of environmental degradation. In this way, there is a clear need for the adoption of conservationist practices that provide the sustainability of environmental systems in the area in focus.
\end{abstract}

Keywords: Physical environment; Human occupation; Systemic analysis. 
Aspectos geoambientais das áreas de nascentes no alto curso da sub-bacia hidrográfica do rio Figueiredo/Ceará

Diêgo Souza Albuquerque; Maria Losângela Martins de Sousa

\section{Introdução}

O desenvolvimento dos estudos geoambientais se mostra copioso e indispensável. Estes, possibilitam compreender as dinâmicas naturais e os reflexos antrópicos na configuração atual da paisagem e dos recursos naturais, elucidando impactos e acendendo possibilidades de reversão de quadros de degradação e adoção de atitudes sustentáveis de convivência com o meio.

Para a consolidação desse tipo de apreciação, é preciso o conhecimento integrado e holístico da totalidade do recorte que se estuda, cabendo interpretações setorizadas que precede as análises sistêmicas. Essas interpretações servem ao planejamento ambiental, consequentemente, a gestão mais eficiente do território.

Nesse primeiro momento, o levantamento do conjunto setorizado dos elementos do ambiente local (meio físico e ocupação humana) representa um diagnóstico inicial, e é importante para estabelecer, seguidamente, as relações sistêmicas nesse ambiente, interpretando o comportamento e interações entre esses elementos na configuração da paisagem. Dessa forma, a abordagem sistêmica converge na aproximação dos estudos setoriais, conduzindo a uma posterior integração dos componentes da paisagem, possibilitando, então, o conhecimento da sua dinâmica (SOUZA; OLIVEIRA, 2011).

Considerando a unidade da bacia hidrográfica $(\mathrm{BH})$ como parte territorial, essa necessita ser melhor compreendida, haja vista sua importância no gerenciamento dos recursos hídricos disponíveis e disponibilizados à população. Conforme Botelho (1999), a BH é uma unidade de análise da superfície terrestre, de modo que permite reconhecer e estudar as interrelações existentes entre os diversos elementos da paisagem que a compõe e os processos que atuam na sua esculturação. Nesse contexto, é cogente repensar a sustentabilidade dos recursos naturais na $\mathrm{BH}$, buscando compreender suas vulnerabilidades e potencialidades.

Nessa unidade, as áreas de nascentes dos cursos d'água são partes intrínsecas. As nascentes são formações ambientais de reconhecida importância na dinâmica da BH ao passo que auxiliam na origem e disponibilidade dos recursos hídricos. Notadamente, as nascentes devem ser preservadas com vista a manter a dinâmica hidrológica local e do meio. Desse modo, esses ambientes auferem a necessidade de preservação, necessidade essa imperada na Lei Brasileira de Proteção da Vegetação Nativa de nº 12.651/2012, que delimita as nascentes como Área de Preservação Permanente (BRASIL, 2012).

Alicerçado no contexto em evidência, o presente trabalho vem tratar da contextualização geoambiental das áreas de nascentes no alto curso da sub-bacia hidrográfica do rio Figueiredo, estado do Ceará. Para tanto, aborda os elementos da base geológica, das 
feições geomorfológicas, do envoltório hidroclimático, dos elementos fitopedológicas e do histórico de ocupação do objeto em evidência.

Esse diagnóstico inicial compreende e sistematiza elementos ao conhecimento da área, que são indispensáveis as interpretações sistêmicas mais profícuas posteriores, como a delimitação dos sistemas ambientais. Logo, essa revelação inicial do arcabouço geoambiental denota a importância deste trabalho.

A construção da presente pesquisa pautou-se em quatro etapas: revisão bibliográfica e compilação do material geocartográfico disponível; elaboração de mapas básico e temático da área; realização de trabalho de campo para conhecimento da verdade terrestre e registros fotográficos; e interpretação dos dados e construção do produto final.

\section{Localização Geográfica}

A sub-bacia hidrográfica do rio Figueiredo (SBHRF) está situada na porção leste do estado do Ceará, drena uma área de aproximadamente $2320 \mathrm{~km}^{2}$, constituindo-se como o principal afluente da bacia hidrográfica do Médio Jaguaribe, pela sua margem direita, e tem como canal principal o rio Figueiredo, que nasce no município de Pereiro e deságua no rio Jaguaribe, em São João do Jaguaribe (SOUSA, 2012).

Delimitou-se como lócus de estudo as áreas de nascentes no alto curso da SBHRF por estas apresentarem o início de três importantes canais fluviais da sub-bacia, a saber: rio Figueiredo, o riacho Amparo e o riacho Jatobá, todos de nascentes intermitentes. A área de estudo possui extensão de aproximadamente $681 \mathrm{~km}^{2}$. Sua dimensão é composta por territórios municipais de Pereiro (35\%), Ereré (42,7\%) e Iracema (22,3\%). O recorte limita-se a norte com o médio curso da sub-bacia do rio Figueiredo, ao sul e oeste com o Maciço do Pereiro e bacia do Médio Jaguaribe e a leste faz divisa com a bacia hidrográfica do rio ApodiMossoró, estado do Rio Grande do Norte. Na figura 1, é evidenciado a localização geográfica da área em estudo e a dimensão da sub-bacia hidrográfica do rio Figueiredo. 
Aspectos geoambientais das áreas de nascentes no alto curso da sub-bacia hidrográfica do rio Figueiredo/Ceará

Diêgo Souza Albuquerque; Maria Losângela Martins de Sousa

Figura 1: Localização da área de estudo.

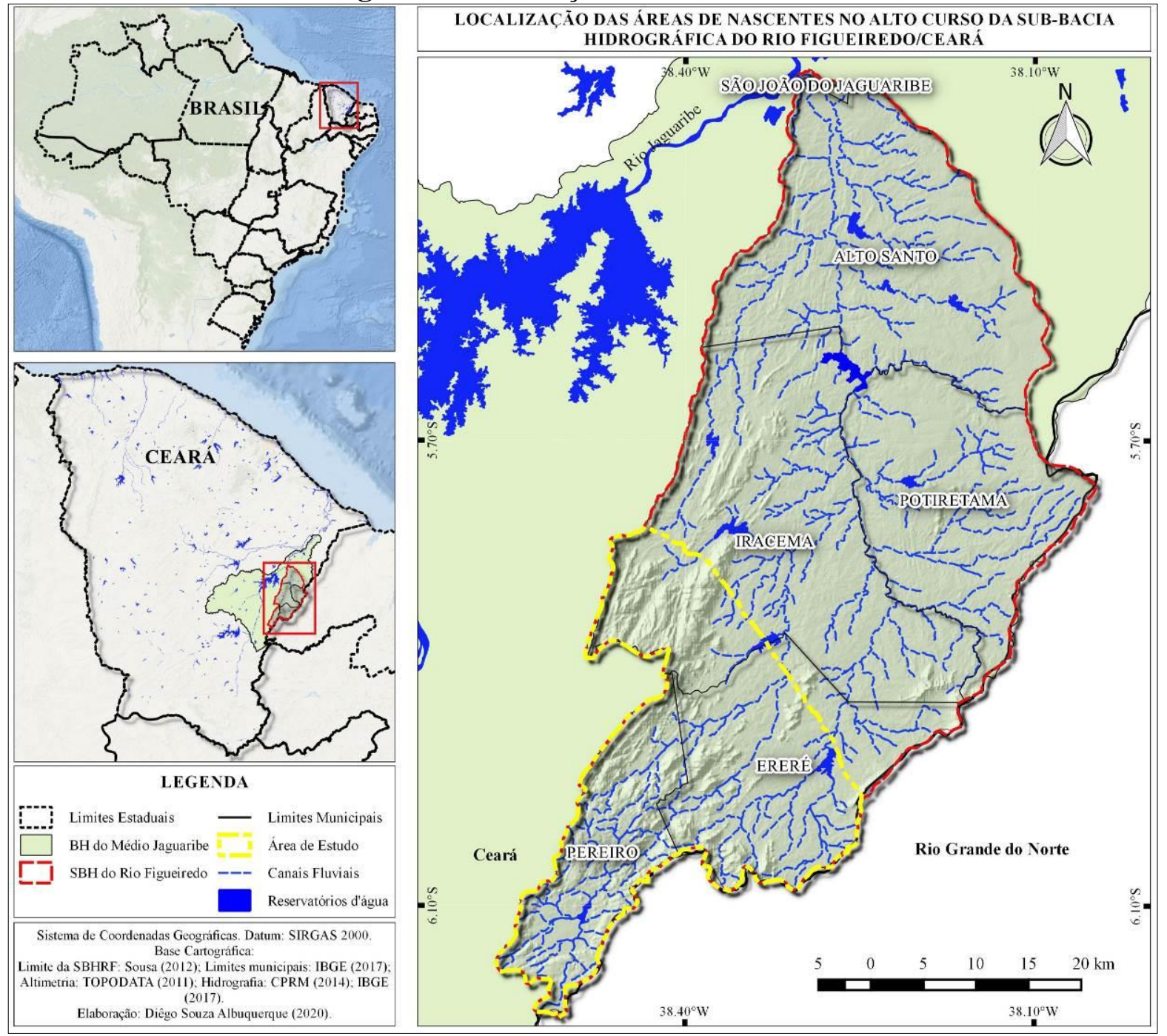

Fonte: Elaborado pelo autor (2020).

\section{Procedimentos Técnicos-metodológicos}

A delimitação do campo de estudo e o mapeamento foi produzido no Software QGIS versão 2.18 'Las Palmas'. A cartografia foi trabalhada na escala de 1:150.000. Adotou-se o Datum SIRGAS 2000, o Sistema de Coordenadas Planas - UTM, fuso 24 Sul para os mapas temáticos.

Para a elaboração dos mapas de geologia e geomorfologia foram utilizadas os shapefiles das unidades litoestratigráficas e do relevo presentes na malha digital em formato vetorial da Geodiversidade do Estado do Ceará, produzidos pelo Serviço Geológico do Brasil (CPRM, 2014) em escala de 1:750.000. Fez-se consulta também no Mapa Geológico do estado do Ceará (CPRM, 2003) com escala de 1:500.000. Foram analisadas a distribuição dos tipos litológicos, sendo esses agrupados por formações e identificado a crono-litoestatigrafia. 
Aspectos geoambientais das áreas de nascentes no alto curso da sub-bacia hidrográfica do rio Figueiredo/Ceará

Diêgo Souza Albuquerque; Maria Losângela Martins de Sousa

Acessório as unidades de relevo do levantamento geocartográfico citado, foram geradas informações da hipsometria e declividade do terreno, por meio de dados SRTM (Shuttle Radar Topography Mission), do projeto TOPODATA, disponibilizados pelo Instituto Nacional de Pesquisas Espaciais (INPE), em formato GeoTiff, sendo realizado a miscelânea das imagens 05s_39_e 07s_39_e posterior recorte para área em estudo.

Quanto ao envoltório hidro-climático foi consultado o mapa dos Tipos Climáticos do Ceará, disponibilizado pelo Instituto de Pesquisa e Estratégia Econômica do Ceará (IPECE, 2007). A rede de drenagem foi adquirida na base de dados em formato vetorial do Instituto Brasileiro de Geografia e Estatística (IBGE, 2017). Para fomentar a discussão hidroclimática, valeu-se de pesquisas acerca dos estudos climáticos para a região Nordeste, evidenciando dinâmicas meteorológicas influenciadoras no clima regional e local. Foi realizado análises das séries históricas de precipitação disponibilizados pela Fundação Cearense de Meteorologia (FUNCEME) em estações pluviométricas presentes nos municípios de Pereiro, Ereré e Iracema. Foi verificado a temperatura do ar, utilizando o programa de estimativa de temperatura Estima_T, criado pelo Departamento de Ciências Atmosféricas, da Universidade Federal de Campina Grande, sendo gerado uma série história do período de 1973 a 2003, que compreende 30 anos, para serem feitas as análises para a área de estudo.

Quanto as condições fitopedológicas, foram considerados o Mapa de ReconhecimentoExploratório de Solo do Estado do Ceará (CEARÁ, 1973) e o Mapa de Classes de Solos do estado do Ceará do IPECE. Esses foram georreferenciados para a área de estudo. Acessório, foi considerado o estudo morfopedológico e listagem da composição florística organizado por Sousa (2012) para a SBHRF, bem como foi feito reconhecimento de tipos pedológicos e observado as composições vegetais da área através das atividades de campo.

No trabalho de campo foram utilizadas as folhas topográficas Iracema (MI972-SB-24X-C-V), Orós (MI1048-SB-24-Z-A-I) e Pau dos Ferros (MI1049-SB-24-Z-A-II), que compõem a Base Cartográfica Digital do estado do Ceará, disponibilizada pelo IPECE, elaborada a partir da vetorização das cartas topográficas da SUDENE na escala 1:100.000, datadas de 1970. Fez-se uso da ficha de campo proposta pelo professor Marcos Nogueira de Souza para realização da análise geoambiental, além de um GPS Garmin Etrex 10. Foram feitos também os registros fotográficos, com a finalidade de evidenciar a verdade terrestre da área, servindo de apoio para a tipologia da paisagem.

Para a compreensão do histórico de ocupação da área de estudo, foi necessária revisão bibliográfica, pautada principalmente em Ferreira Neto (2003; 2019), Silva e Alencar (2015) e Chaves (2016). 
Aspectos geoambientais das áreas de nascentes no alto curso da sub-bacia hidrográfica do rio Figueiredo/Ceará

Diêgo Souza Albuquerque; Maria Losângela Martins de Sousa

\section{Contexto Geoambiental das Áreas de Nascente no Alto Curso da Sub-bacia Hidrográfica do Rio Figueiredo/Ceará}

\section{Base Geológica}

A Geologia, aliada as condições climáticas, é reconhecida como base para a estruturação dos outros componentes geoambientais, como das unidades geomorfológicas, da formação da rede hidrográfica e dos tipos pedológicos. Desta feita, se faz necessário conhecer as unidades litoestratigráficas da área de estudo para então articular sua existência com as feições de relevo e a dinâmica externa atuante ao longo do tempo.

A unidade litoestratigráfica é compreendida como um conjunto rochoso caracterizado por um tipo ou combinação de vários tipos rochosos que podem se constituir de tipos sedimentares, ígneas ou metamórficas, separadas ou intercaladas, consolidadas ou inconsolidadas (BRASIL, 1998). Essas unidades possuem como característica a sua individualização, permitindo destacá-la das outras adjacentes, bem como sua expressão geográfica determinada pela continuidade.

Em contexto geológico geral, a área de estudo está inserida nos domínios da Província Borborema, que ocupa grande parte do Nordeste brasileiro, especificamente no setor setentrional desta, ocupando o domínio Jaguaribeano. Em expressão cearense, a área de estudo apresenta dois domínios morfoestruturais definido por Souza (1988): Domínio dos Depósitos Sedimentares Cenozoicos e o Domínio dos Escudos e Maciços Antigos PréCambrianos. O primeiro compreende pequena parte da área, correspondendo as planícies fluviais, enquanto o segundo ocupa maior expressão correspondente a Superfície de Aplainamento e ao Maciço do Pereiro.

As unidades litoestratigráficas da área de nascentes são: Suíte Granitóide Serra do Deserto, Grupo Serra de São José, Complexo Jaguaretama, Grupo Orós, todas de cronoestratigráfia paleoproterozóica; Suíte Granitóide Intrusiva Itaporanga, Suíte Gabróide (Suíte Mórfica), ambas são formações Neoproperozóica; e os Depósitos Aluviais CenozoicoQuaternário (CPRM, 2003; 2014).

O Depósito Aluvial (Q2a) é uma superfície plana, formada pela deposição de sedimentos como argilas, areias argilosas, quartzosas e quartzofeldspáticas e cascalhos. Sua maior expressão é encontrada próximo a sede de Ereré, porém, pode ser encontrada nos outros riachos de modo mais discreto (CPRM, 2003).

A Suíte Granitóide Serra do Deserto (PP4sd) é vista na porção noroeste e sudoeste do recorte, vinculada a formação de relevo Maciço do Pereiro (MP), sendo composta por augen 
Aspectos geoambientais das áreas de nascentes no alto curso da sub-bacia hidrográfica do rio Figueiredo/Ceará

Diêgo Souza Albuquerque; Maria Losângela Martins de Sousa

ortognaisses graníticos, biotita, tonalitos e quartzodioritos, sendo intensamente fraturada. $\mathrm{O}$ Grupo Serra de São José (PP4sj) está presente em uma pequena porção do sudeste da área, município de Ereré, formada por biotita, paragnaisses, quartzitos, xistos e metatufos, sendo intensamente fraturada com intemperismo físico predominante (CPRM, 2003; 2014).

O Complexo Jaguaretama ( $\mathrm{PPj}$ ) compreende considerável porção da área, estando vinculado a expressão da Superfície de Aplainamento, composta por ortognaisses, granito, tonalito, paragnaisses, quartzitos e rochas calcissilicáticas, sendo intensamente fraturada com intemperismo físico e químico e porosidade baixa (CPRM, 2003; 2014).

O Grupo Orós (PP4oqg) se encontra na porção noroeste da área. Sua composição é de formação gnáissica, expressada em quartzitos associados a paragnaisses e, localmente, a gnaisses e metatufos (CPRM, 2003; 2014).

A Suíte Granitóide Intrusiva Itaporanga (NP3y2i) é a maior expressão da área, espraiando-se na faixa sul, oeste, sudoeste e noroeste. Ela está expressivamente ligada ao Maciço do Pereiro - seu platô, vertentes, suas fisionomias colinosas e formadas em cristas, erodidas e dissecadas - e a Serra dos Remédios. Sua composição compreende granitos e granodioritos de granulação grossa e porfiríticos, associados a dioritos, sendo pouco a moderadamente fraturada com intemperismo físico e químico moderada a alta atividade.

A unidade Suíte Gabróide/Suíte Máfica (NP32) compreende porção no sudoeste da área, no município de Pereiro, com fisionomia arredondada e superfície plana, margeada pelas bordas mais altas do Maciço do Pereiro. Outro trecho dessa unidade fica no limítrofe de Pereiro-Ereré, situado em uma considerável porção das vertentes serranas, acompanhado o dessecamento do vale do rio Figueiredo. Essas unidades se encontram em fisionomias de relevo contrárias, marcadas pelo aplainamento de uma e pela declividade acentuada da outra. É comporta por dioritos, gabros, tonalitos, quartzomonzonitos e granodioritos. Na figura 2 é apresentado a Geologia e o Relevo da area de estudo.

As Unidades Suíte Serra do Deserto, Suíte Serra de São José, Complexo Jaguaretama e Suíte Granitóide Itaporanga, dotadas de rochosidade ígnea e metamórfica, apresentam baixa porosidade, em torno de 0 a $15 \%$, em virtude do seu sistema hidrogeológico fissural. Isso posto, conclui-se que há abundantemente o escoamento superficial das águas pluviais, pois são litologias que possuem baixa capacidade de absorção. Dessa forma, não permitem acentuadas reservas de águas subterrâneas na área, acentuando a problemática da escasses hídrica, principalmente no município de Pereiro, uma vez que seu território está composto em maior parte por essas litologias. 
Aspectos geoambientais das áreas de nascentes no alto curso da sub-bacia hidrográfica do rio Figueiredo/Ceará

Diêgo Souza Albuquerque; Maria Losângela Martins de Sousa

Figura 2: Unidades Crono-litoestratigráficas e de Relevo da área de estudo.

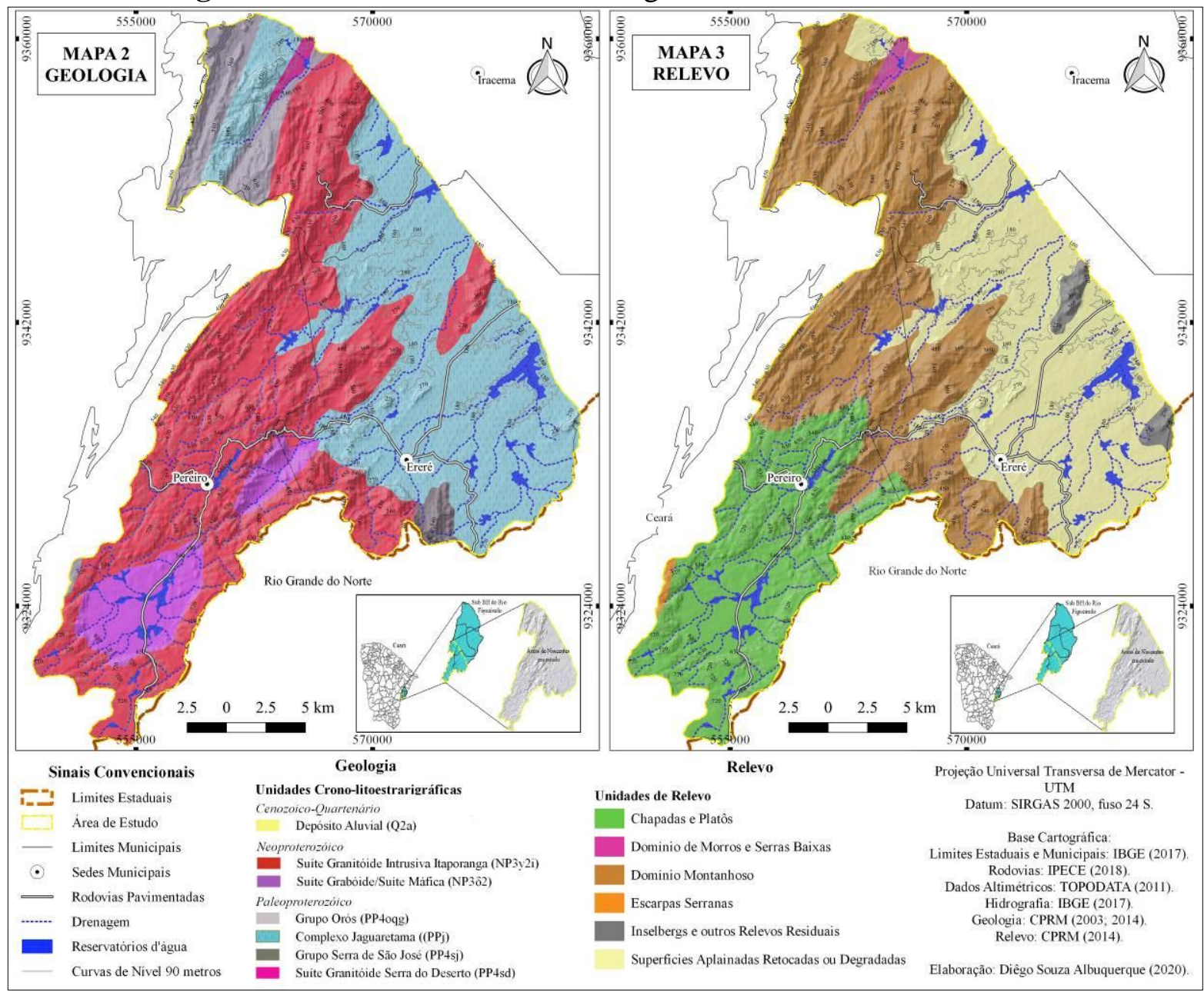

Fonte: Elaborado pelo autor (2020).

\section{Feições Geomorfológicas}

O relevo são feições e formas que compõem a superfície terrestre, cujo arranjo espacial se mantem em função do substrato rochoso que as sustentam e dos processos internos e externos que as geraram e modelam (ROSS, 2012). Sendo o conhecimento geomorfológico fundamental para a implantação de qualquer atividade humana na superfície terrestre.

Maia e Bezerra (2014) discutindo o condicionamento estrutural do relevo no Nordeste setentrional do Brasil, revelam que esse foi descrito classicamente como paleosuperfícies resultantes de ciclos de peneplanação. Entretanto, a partir de pesquisas recentes, compreendese que essa região geomorfológica é controlada por zonas de cisalhamento dúcteis e suas reativações, sendo imprescindível reconhecer a existência de um controle exercido pela erosão diferencial e outro dado pela reativação frágil das zonas de cisalhamento.

Estes dois aspectos são importantes para compreender como ocorre o controle estrutural desse relevo. A área em estudo é resultado desse processo, estando em meio a 
Aspectos geoambientais das áreas de nascentes no alto curso da sub-bacia hidrográfica do rio Figueiredo/Ceará

Diêgo Souza Albuquerque; Maria Losângela Martins de Sousa

Zonas de Cisalhamentos, apresentando porções de um Maciço Estrutural e áreas formadas a partir da dinâmica natural pretérita.

No tocante a área em estudo, Sousa (2012) apresenta que a morfoestrutura é reflexo de aspectos tectônicos e litológicos. Esse primeiro está representado pela existência de falhas e pela adaptação da rede de drenagem às condições rígidas da geologia, enquanto o segundo se apresenta através dos tipos de alterações superficiais e das relações entre morfogênese e pedogênese. Tais aspectos são responsáveis pelo modelado do relevo local.

A partir da CPRM (2014) foram mapeados as seguintes feições geomorfológicas na área: Chapadas e Platôs, Domínio Montanhoso, Domínio de Morros e Serras Baixas, Escarpas Serranas, Inselbergs e outros Relevos Residuais e Superfícies Aplainadas Retocadas ou Degradadas. Tais aspectos do relevo são reflexos das condições geológicas, dos eventos endógenos, bem como dos fatores exógenos, que juntos atuam na morfoesculturação da superfície terrestre local (SOUSA, 2012).

As formas da paisagem em análise pertencem a duas dimensões geomorfológicas: formas denudacionais e agradacionais. A primeira compreende as feições de relevo dissecativo fundado por processos erosivos, com reduzidas taxas de sedimentação, enquanto a segunda apresenta, localmente, o inverso, na qual o processo deposicional é superior ao processo de erosão e transporte de material.

As escarpas serranas do Maciço do Pereiro apresentam formas de dissecação, o que comprova a atuação da erosão diferencial nesse relevo, constituindo de declividades diferenciais, superfícies movimentadas, formas diversas de topos e de esculturação de vales. A Depressão Sertaneja é uma superfície de aplainamento e arrasamento, em que o deslocamento de material é superior a deposição. Assim, as duas formas atestam as feições desnudas na paisagem. A forma deposicional pode ser analisada perante e deposição aluvial, expressa pelas planícies fluviais existentes.

As formas Chapadas e Platôs, Domínio Montanhoso, Domínio de Morros e Serras Baixas, Escarpas Serranas, Superfícies Aplainadas Retocadas ou Degradadas e Inselbergs e outros Relevos Residuais estão vinculados ao contexto denudacional. As Superfícies Aplainadas são formações influenciadas pela dinâmica do Maciço do Pereiro, que ao longo da SBHRF ganham feições diferenciadas como atesta Sousa (2012), sendo que à medida que se distancia do Maciço, essa se torna menos ondulada e mais plana.

A Unidade Chapadas e Platôs compreende a parte sudoeste da área. Os setores dessa unidade compreendem domínios litoestratigráficos da Suíte Granitóide Intrusiva Itaporanga e da Suíte Gabróide. As cotas hipsométricas estão entre 517 a 770 metros e a declividade varia 
Aspectos geoambientais das áreas de nascentes no alto curso da sub-bacia hidrográfica do rio Figueiredo/Ceará

Diêgo Souza Albuquerque; Maria Losângela Martins de Sousa

de 3 a $20^{\circ}$, suave à ondulado. Nessa mesma porção da área, localiza-se a unidade Escarpa Serrana, de menor proporção, com condições geológicas da Suíte Serra do Deserto e Suíte Itaporanga. Essa unidade é uma pequena porção da escarpa de falha estrutural da Zona de Cisalhamento do Jaguaribe que sustenta o Maciço Estrutural Pereiro (MAIA; BEZERRA, 2014). Essa área possui vertentes íngremes, com declividade máxima de $45^{\circ}$ e cota altimétrica que se enquadra na categoria entre 644 a 720 metros.

A unidade Domínio Montanhoso se estende na direção sudeste-noroeste, distribuída entre os municípios de Ereré, Pereiro e Iracema. Essa compreende litologia da Suíte Itaporanga, do Completo Jaguaretama, das Suíte Serra de José e Serra do Deserto. Suas cotas variam nas classes entre 390 a 644 metros, apresentando declividade predominante entre $8^{\circ} \mathrm{e}$ acima de $45^{\circ}$. Percebe-se que os processos de erosão induziram à dissecação de suas feições.

As três unidades acima formam, na área de estudo, o Maciço do Pereiro, que consiste em um alinhamento serrano encimado por um extenso platô delimitado por uma escarpa voltada para o vale do rio Jaguaribe (CPRM, 2014). O mesmo corresponde a um Planalto Residual/Estrutural Sertanejo. Esse maciço de rochas cristalinos implicam no escoamento superficial das chuvas torrenciais, construindo padrões de drenagens dendríticos, contribuindo para a modelagem do relevo em superfícies dissecadas. O regime de precipitação influenciada pelo maciço, mesmo que minimamente, favorece um microclima mais ameno que potencializa o desenvolvimento de solos mais profundos e vegetação mais exuberante.

A Unidade Domínio de Morros e Serras Baixas corresponde a uma pequena porção de relevo localizada no município de Iracema. Sua altitude está entre 180 a pouco mais de 200 metros, apresentando declividade suave na classe de 3 e $8^{\circ}$.

Os Inselbergues e outros Relevos Residuais se inserem na categoria de relevo ondulado e apresentam alinhamento topográfico com topos em cristas e colinosos, se constituindo por rochas mais resistentes que as do entorno rebaixado. Essas formas atingem altitudes na cota máxima de 360 metros, possuem vertentes lineares e convexas com declividade que varia de 8 a $45^{\circ}$. É visível a dificuldade no desenvolvimento quanto a pedogênese nessa formação, o que se comprova pelo afloramento granítico local.

As Superfícies Aplainadas Retocadas ou Degradadas estão sobre litologia do Complexo Jaguaretama. Segundo Maia e Bezerra (2014), a complexidade litológica dessa formação dificulta sua caracterização geológica. Todavia, destacam o predomínio de um substrato mineralógico rochoso resultante do metamorfismo que ocorreu no Pré-cambriano e tal característica controla a erosão diferencial que ocorreu no Cenozóico. A unidade de 
Aspectos geoambientais das áreas de nascentes no alto curso da sub-bacia hidrográfica do rio Figueiredo/Ceará

Diêgo Souza Albuquerque; Maria Losângela Martins de Sousa

superfície pediplanada se enquadra na categoria de relevo plano à ondulado, fisionomia presente em áreas semiáridas cearenses, e suas cotas altimétricas não ultrapassam 270 metros.

Nessa forma de relevo, o embasamento cristalino, dotado de impermeabilidade, não condiciona expressivas reservas d'águas subterrâneas, o que demandou a construção de reservatórios superficiais para acúmulo desse recurso. Em decorrência desse embasamento há existência de chãos pedregosos, sendo florestados por caatingas. Na figura 3 estão dispostas diferentes feições do relevo da área.

Figura 3: Feições das formas de relevo. (A) Unidade Chapadas e Platôs - Pereiro; (B) Unidade Domínio Montanhoso - Ereré; (C) Unidade Inselberg e outros Relevos Residuais Ereré; (D) Unidade Superfícies Aplainadas Retocadas ou Degradadas - Ereré.
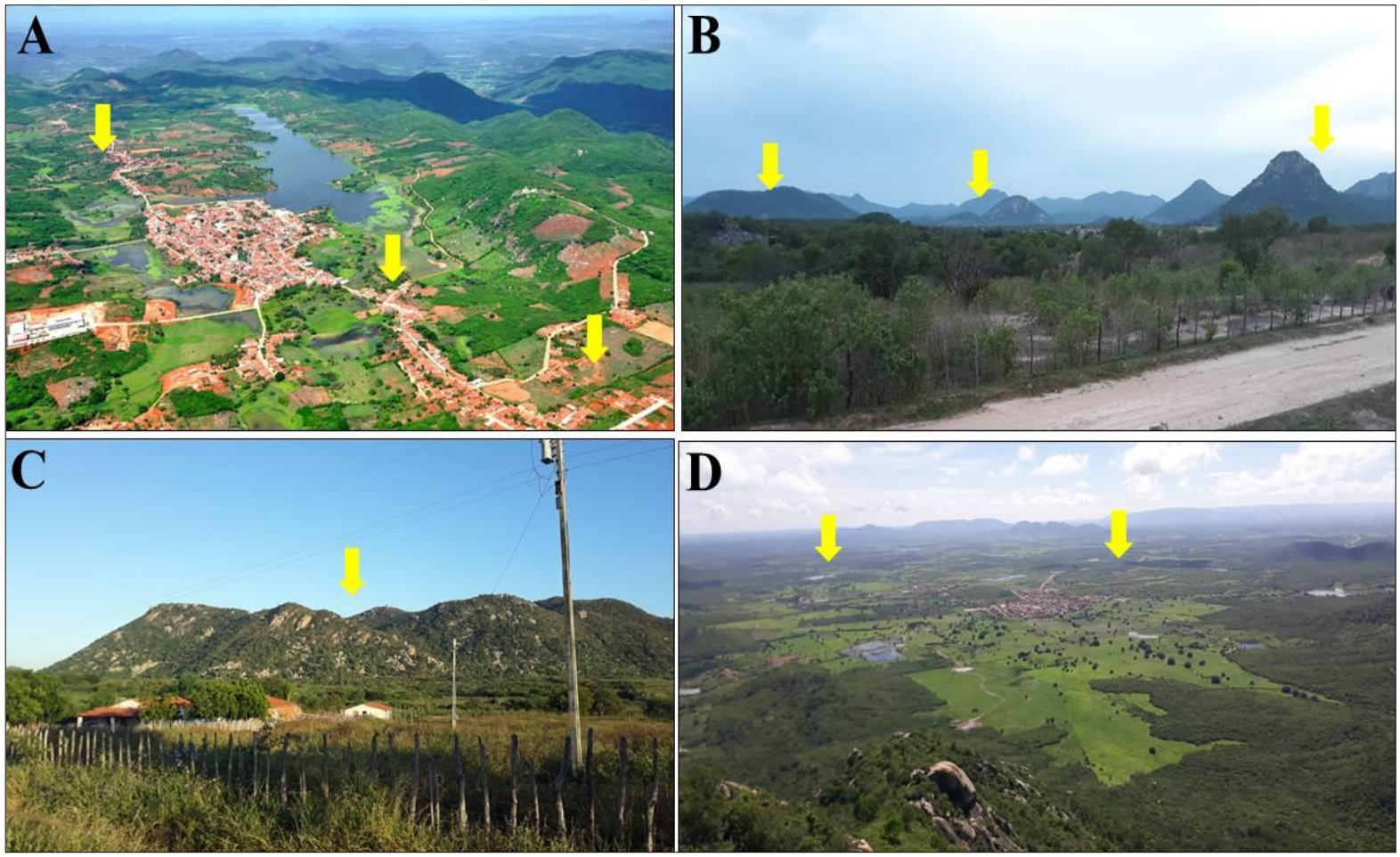

Fonte: (A) Aires, 2012; (B, C, D) Acervo do autor, 2019.

\section{Aspectos Hidroclimáticos}

Em uma compreensão sistêmica, os fatores climáticos podem responder a questões referentes aos processos formadores, numa estrutura espaço-temporal, de sistemas geográficos, tanto naturais quanto antrópicos (SANT'ANNA NETO, 1998). O clima se torna um importante elemento no estudo geográfico, uma vez que esse ou, processos dele originados, podem transformar a paisagem e causar problemas de ordem social e econômica.

No contexto nordestino, o clima predominante é o Tropical Semiárido. Segundo Nunes (2006) esse clima é caracterizado por temperaturas muito elevadas, sempre acima de 
Aspectos geoambientais das áreas de nascentes no alto curso da sub-bacia hidrográfica do rio Figueiredo/Ceará

Diêgo Souza Albuquerque; Maria Losângela Martins de Sousa

$30^{\circ} \mathrm{C}$, chuvas escassas e mal distribuídas espaço-temporalmente. A semiaridez resulta em uma cobertura vegetal caduca, adaptada a evaporação potencial acima de $2000 \mathrm{~mm}$, precipitação em média de $800 \mathrm{~mm}$ e eventos hidrológicos extremos, ocorrendo secas frequentes e cheias excepcionais (VIEIRA; GONDIM FILHO, 2002).

O Ceará, no tocante aos seus atributos climáticos, não foge à realidade regional. De acordo com a FUNCEME no estado há presença de cinco climas, dentre os quais o Tropical Quente Semiárido. As tipologias mais amenas são evidenciadas em áreas de maiores elevações do território, consideradas áreas de enclaves úmidos.

Segundo a caracterização climática do Ceará (CEARÁ, 2007), as áreas de nascentes em estudo recebem a influência de dois tipos climáticos: o Tropical Quente Subúmido e o Tropical Quente Semiárido Brando. Ambos podem apresentar escassez e irregularidade pluviométrica e elevadas taxas de evapotranspiração. No entanto, no primeiro as sensações térmicas são menores, tendo como elemento proporcionador a elevação do Maciço do Pereiro.

Para a análise pluviométrica da área foi gerado a média histórica dos postos trabalhados. Assim, é notório que o posto de Pereiro possui maior média com $964.3 \mathrm{~mm}$, seguido por Ereré com $801.2 \mathrm{~mm}$, e Iracema acumulou a menor média com $788.7 \mathrm{~mm}$. Esses valores foram obtidos mediante o cálculo das precipitações anuais de cada posto e dividido pela quantidade de anos na série (Pereiro e Iracema 39 anos, Ereré 30 anos).

A figura 4 apresenta a distribuição histórica da precipitação por postos pesquisados. Nesse, foi incluido o posto do Distrito de Bastiões, municipio de Iracema. Esses valores foram obtidos mediante cálculo somatório das precipitações mensais, chegando ao cumulativo anual.

Figura 4: Série histórica de precipitação para a área de estudo (1979-2018).

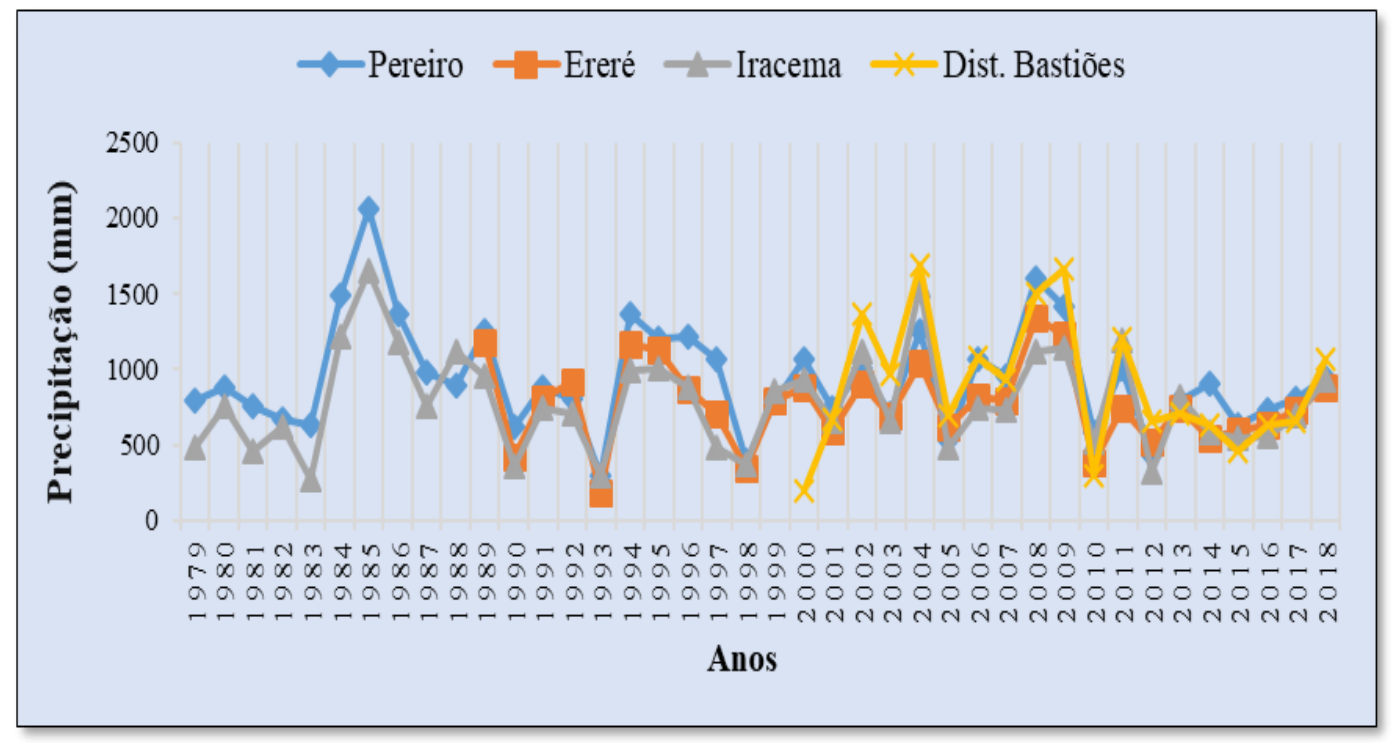

Fonte: Elaborado pelo autor a partir de dados cedidos pela FUNCEME. 
O gráfico apresentou grandes variações pluviométricas. Verifica-se que apesar do município de Pereiro está localizado em uma cota altimetria maior comparado a Iracema e Ereré, isso não influenciou consideravelmente no aumento de suas precipitações na série analisada. No período estudado foi identificado o maior valor de precipitação de 2065,7 mm em 1985 no município de Pereiro, e 185,6 mm a precipitação mínima no ano de 1993 no posto de Ereré.

Os dados extremos de secura na série coincidem como o histórico de secas no Nordeste do Brasil, sendo possível confirmar que os anos de 1983, 1990, 1991, 1993, 1988/99 e 2001 figuram entre aqueles nos quais ocorreram grandes secas.

Segundo a FUNCEME (2016), a ocorrência de secas no estado Ceará após o período supradito, esteve presente no ano de 2010 e no período ente 2012 a 2016, sendo considerado esse último como o pior já registrado. De acordo com a Fundação, a média anual de precipitação desta seca foi de apenas 516 mm, sendo menor que a seca ocorrida entre 1979 a 1983, que apresentou valores de 566 mm média anual. Assim, consideram que a última seca foi a mais grave desde 1910, pois prolongou-se por cinco anos, dificultando o abastecimento hídrico e as atividades produtivas da população.

É importante observar que as médias de precipitação têm evoluído após 2015, rompendo com o quinquênio de secas verificadas, já repercute de forma positiva na vida da população local, visto que essas conseguem (re)iniciar/desenvolver suas atividades produtivas, bem como há a renovação das águas dos reservatórios.

Quanto a caracterização térmica (figura 5), os 3 municípios apresentaram variação em suas médias tanto em caráter comparativo entre si, como entre os seus meses do ano. As temperaturas tendem a cair no mês de março (há também maiores precipitações) e se elevam a partir de agosto até o mês final do ano e primeiro mês do ano seguinte, corroborando com dados térmicos de caracterização regional, sempre próximos ao $24^{\circ} \mathrm{C}$. Pereiro apresentou menores temperaturas do ar, oscilando durante o ano entre $24,6{ }^{\circ} \mathrm{C}$ e $26,3{ }^{\circ} \mathrm{C}$, uma diferença de $2{ }^{\circ} \mathrm{C}$, demonstrando média histórica de $24^{\circ} \mathrm{C}$. 
Aspectos geoambientais das áreas de nascentes no alto curso da sub-bacia hidrográfica do rio Figueiredo/Ceará

Diêgo Souza Albuquerque; Maria Losângela Martins de Sousa

Figura 5: Distribuição da temperatura média do ar mensal dos municípios da área (19732003).

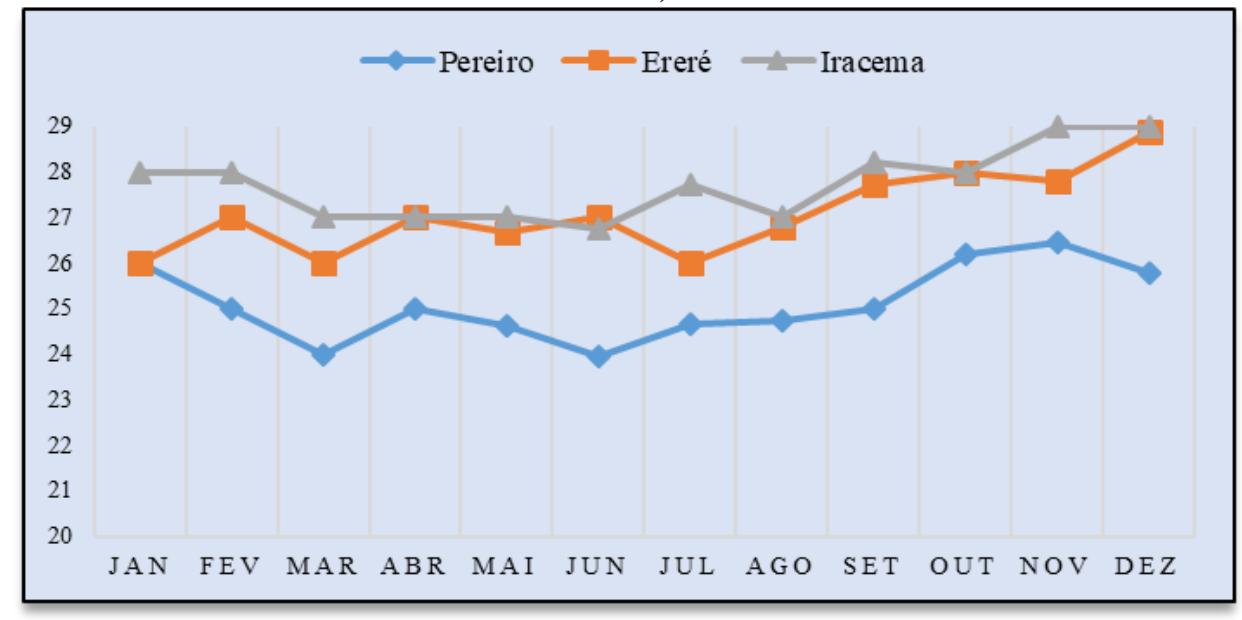

Fonte: Elaborado pelo autor a partir de dados do Estima_T, DCA-UFCG.

Ereré possui temperaturas mais elevadas que Pereiro e menores que Iracema, com média histórica de $26^{\circ} \mathrm{C}$. Sua menor temperatura ocorreu nos meses de janeiro, março e julho, e valor máximo no mês de dezembro. Iracema apresenta maiores temperaturas do ar, com mínima de $26,74^{\circ} \mathrm{C}$ em junho e máxima de $29^{\circ} \mathrm{C}$ em novembro e dezembro. Percebe-se que na área de influência do clima Tropical Quente Subúmido tem-se maiores precipitações e menores temperaturas. Em contrapartida, nos locais influenciados pelo clima Tropical Quente Semiárido Brando tem-se menores precipitações e menores temperaturas.

Esses atributos climáticos, associados às condições geológicas, corroboram para o desenvolvimento de uma política hidráulica de construção de barramentos para armazenar água. As áreas de nascente comportam quatro barramentos monitorados pela Companhia de Gestão dos Recursos Hídricos. Para além desses reservatórios, existem inúmeros outros que têm fundamental importância para a sobrevivência da população rural, contribuindo para o abastecimento humano e usos domésticos, dessedentação animal, aproveitamento de vazantes e pesca, demostrando função indubitável de revitalização daqueles que os podem utilizar.

Esses reservatórios são barramentos artificiais dos riachos. Tais canais são todos de fluxos intermitentes e possuem padrão de drenagem dentrítico. Esses reservatórios são estratégicos para essa área, dada as suas contribuições sociais quando dispõem de água. Dos reservatórios, o Canafístula, em Iracema, possui maior capacidade, com $13.110 .000 \mathrm{~m}^{3}$, formado pelo barramento do riacho Foice, servindo para o abastecimento da cidade de Iracema. No mesmo município se encontra o Açude Santo Antônio, com $832.000 \mathrm{~m}^{3}$ de capacidade, barrando o riacho Jatobá. Ambos são obras construídas pelo estado. 
O açude Santa Maria com capacidade de $5.866 .800 \mathrm{~m}^{3}$, construído a partir do barrando do riacho do Amparo está localizado no município de Ereré. O açude Adalto Bezerra está situado em Pereiro com capacidade de $5.250 .000 \mathrm{~m}^{3}$. Este é o único construindo a partir da atuação do DNOCS em 1984, sendo construído na bacia do riacho São Caetano. O Adalto Bezerra abastecia a cidade de Pereiro até colapsar por falta de água.

O município de Pereiro exibe maiores médias pluviométricas, no entanto, convive com sérios problemas de falta d'água. A declividades e o embasamento cristalino dificulta o armazenamento d'água, seja subterrâneo ou superficial. No município de Ereré essas condições já se modificam. Por estar situado em áreas mais baixas e contar com a presença de planícies fluviais mais desenvolvidas, dispõem de um potencial de águas subterrâneas que abastece a sede do município, bem como seus distritos e comunidades rurais.

\section{Elementos Fitopedológicos}

O solo e a vegetação possuem efetiva relação de manutenção na dinâmica geoambiental, sendo que a presença de um repercute no equilíbrio do outro e vice-versa. Para Souza (2000) a degradação da vegetação diminui a matéria orgânica dos solos, modificando suas propriedades físicas, que repercute na diminuição da capacidade de retenção de água por esse, consequentemente, negativando o desenvolvimento da cobertura vegetal.

Quanto a caracterização vegetacional, a área de estudo apresenta caatinga, mata seca e mata ciliar. A caatinga é endêmica do domínio semiárido brasileiro. Decorrente da semiaridez, surge essa vegetação reconhecidamente xerófila, adaptada ao habitat seco, destaca-se sua caducifolia, perdendo suas folhas no período seco do ano para reter líquido em seu interior e diminuir o processo de fotossíntese (FERNANDES, 2006).

Em toda a área trabalhada há presença de caatinga, desde as áreas mais baixas (150 metros) até as mais elevadas (> 700 metros). Isso comprova transformações nesse ambiente ao longo do tempo, representado pela expansão da caatinga para as áreas mais elevadas que, originalmente, deveria ser florestada por mata seca. Isso pode ser consequência dos vultuosos desmatamentos na área, abrindo caminhos para que espécies caducifólias se desenvolvem-se em altitudes mais elevadas.

Segundo Fernandes (2006), a mata seca é caracterizada por não perder todas as suas folhas em período do estio, incluída como subcaducifólia. Esse tipo de vegetação costuma cobrir encostas de serras subúmidas ou secas no Nordeste brasileiro, com elevação acima dos 500 metros. Como atesta Sousa (2012), a mata seca ou Floresta Tropical Subcaducifólia recobre as encostas e topos da Serra do Pereiro, entre altitudes de 500 a 700 m, sendo que, 
Aspectos geoambientais das áreas de nascentes no alto curso da sub-bacia hidrográfica do rio Figueiredo/Ceará

Diêgo Souza Albuquerque; Maria Losângela Martins de Sousa

atualmente, esta formação é reduzida, e isso se comprova nos trabalhos do campo, existindo poucas áreas que caracterizam essa unidade. Solos mais desenvolvidos e condições climáticas mais amenas são fatores essenciais para a existência dessa formação vegetal nesse ambiente.

A mata ciliar é uma importante formação vegetal que segue os cursos dos rios, os protegendo de processos erosivos em suas margens, contrastando com o ambiente vizinho por seu conjunto verdejante, em razão das melhores condições aluvionais. Na área em estudo essa formação tem sofrido maciça degradação, mediante sua retirada para aproveitamento do potecial das margens dos canais fluviais pelas populações locais.

Quanto ao recobrimento pedológico, há uma variedade de classes de solos. Segundo Ceará (1973) e o Mapa de Classes de Solos do Ceará do IPECE, recobrem a área em estudo associações de Argissolos, Luvissolos, Neossolos Litólicos e Latossolos. No quadro 1 são apresentas as classes de solos, os perfis identificados na área e suas características predominantes. A classe dos Vertissolos, Neossolos Flúvicos e Planossolos não consta no mapeamento apontado, sendo que esses foram identificados mediante trabalho campo.

Quadro 1: Descrição das classes de solos presentes na área de estudo.

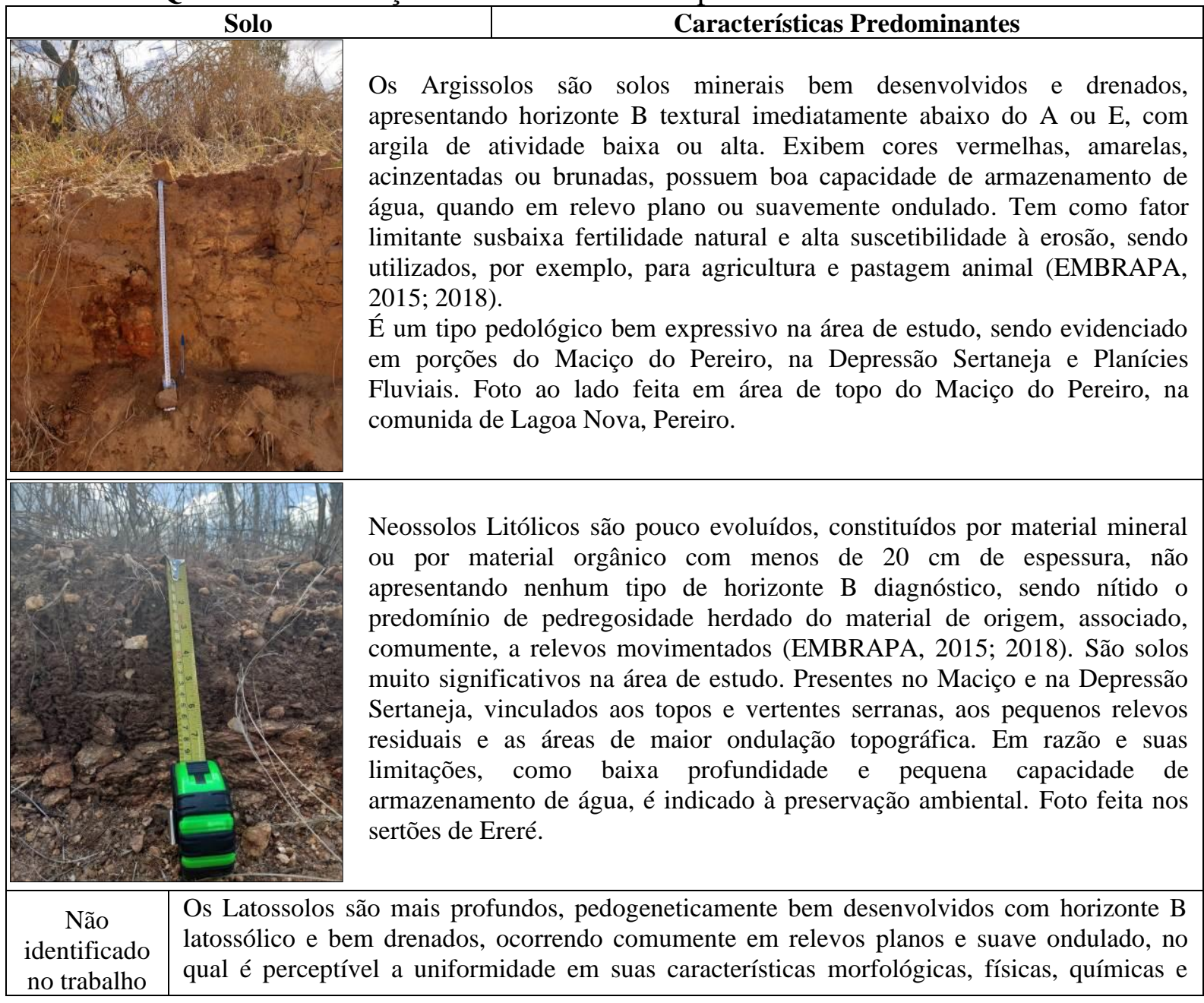




\section{Aspectos geoambientais das áreas de nascentes no alto curso da sub-bacia hidrográfica do rio Figueiredo/Ceará \\ Diêgo Souza Albuquerque; Maria Losângela Martins de Sousa}

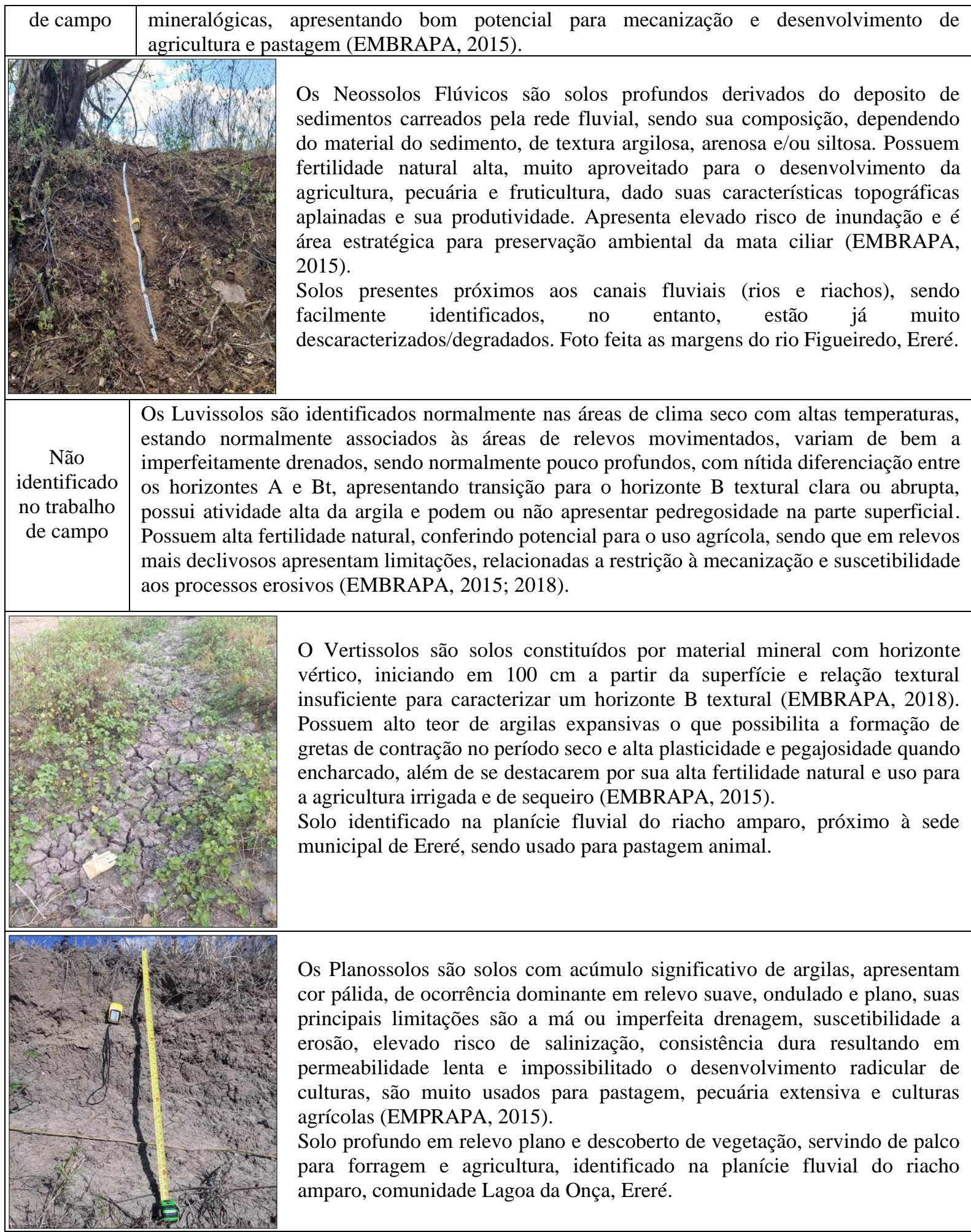

Fonte: Elaborado pelo autor (2020).

Nas áreas de relevo mais planos e suaves, com circulação e maior potencial de infiltração de água, geralmente são encontrados solos mais desenvolvidos e profundos, enquanto que nos ambientes mais movimentados e de escoamento superficiais mais efetivos, 
Aspectos geoambientais das áreas de nascentes no alto curso da sub-bacia hidrográfica do rio Figueiredo/Ceará

Diêgo Souza Albuquerque; Maria Losângela Martins de Sousa

os solos são mais jovens e rasos, apresentando componentes ainda inconsolidados, a exemplos dos detritos rochosos, formando pavimentos dentrítico.

Nos relevos residuais e nos sertões são comuns os afloramentos rochosos, demostrando a rigidez do material geológico e se associado aos cobrimentos pedológicos. Esses ambientes são cenários, salve exceções, de "jardins" de cactáceas que se desenvolvem sobre o material rochoso, aproveitandos as fissuras. $\mathrm{O}$ quadro 2 apresenta uma relação fitopedológicas para a área de estudo.

Quadro 2: Fitopedologia da área de estudo, paragrafado nas macroforma de relevo.

\begin{tabular}{|c|c|c|c|}
\hline $\begin{array}{c}\text { Macroforma } \\
\text { de relevo }\end{array}$ & $\begin{array}{c}\text { Associações de } \\
\text { Solos }\end{array}$ & $\begin{array}{c}\text { Associações da } \\
\text { Vegetação }\end{array}$ & Espécies Encontradas \\
\hline $\begin{array}{l}\text { Maciço do } \\
\text { Pereiro }\end{array}$ & $\begin{array}{l}\text { Argissolos } \\
\text { associados aos } \\
\text { Luvissolos, } \\
\text { Neossolos Litólicos, } \\
\text { Latossolos e } \\
\text { afloramentos de } \\
\text { rochas nas cristas e } \\
\text { vertentes do relevo } \\
\end{array}$ & $\begin{array}{l}\text { Mata } r \text { Seca } \\
\text { associada } \\
\text { Caatinga } \\
\text { Arbórea/Arbustiv } \\
\text { a e extensão de } \\
\text { capoeiras. }\end{array}$ & 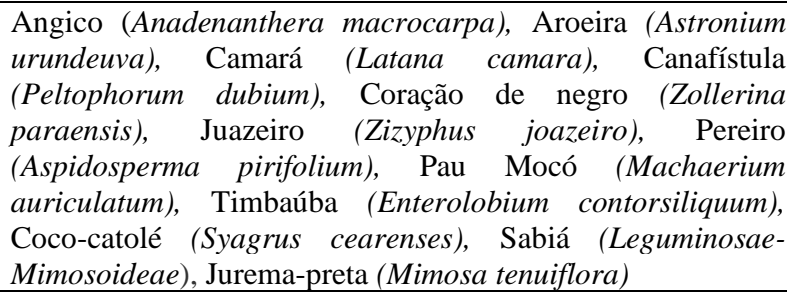 \\
\hline $\begin{array}{l}\text { Superfícies } \\
\text { Aplainadas }\end{array}$ & $\begin{array}{l}\text { Associação dos } \\
\text { Argissolos, } \\
\text { Neossolos Litólicos } \\
\text { com Luvissolos e } \\
\text { afloramentos de } \\
\text { rochas }\end{array}$ & $\begin{array}{l}\text { Caatinga } \\
\text { Arbustiva } \\
\text { variando de densa } \\
\text { e aberta por ora } \\
\text { degradada, } \\
\text { formações } \\
\text { herbáceas, } \\
\text { cactáceas } \\
\begin{array}{l}\text { extensão } \\
\text { capoeiras }\end{array} \\
\end{array}$ & $\begin{array}{l}\text { Ameixa (Ximenia coriácea), Angico (Anadenanthera } \\
\text { macrocarpa), Camará (Latana camara), Cardeiro (Cereus } \\
\text { adscendens), Catingueira (Caesalpinia bracteosa), Cumarú } \\
\text { (Torresca cearensis), Jurema Branca (Pithecolobium } \\
\text { dumosum) Jurema Preta (Mimosa nigra), marmeleiro (Croton } \\
\text { henargyreus), Sabiá (Mimosa caesalpiniaefolia) Capim } \\
\text { panasco (Panicum capilaceum), Xique-xique (Pilosocereus } \\
\text { gounellei), Mofumbo (Combretum leprosum), Carnaúba } \\
((\text { Copernicia prunifera) e Velame (botânica) }\end{array}$ \\
\hline $\begin{array}{c}\text { Planícies } \\
\text { Fluviais }\end{array}$ & $\begin{array}{l}\text { Associação de } \\
\text { Neossolos Flúvicos, } \\
\text { Argissolos } \\
\text { Planossolos }\end{array}$ & $\begin{array}{l}\text { Mata } \\
\text { associada } \\
\text { espécies } \\
\text { caatinga }\end{array}$ & $\begin{array}{l}\text { Carnauba (Copernicia cerifera), Juazeiro (Zizyphus joazeiro), } \\
\text { Oiticica (Licania rigida), Murici (Byrsonima verbascifolia), } \\
\text { Pau Branco (Auxemma oncocalyx), Velame (Croton } \\
\text { campestris), Canafístula (cássia-imperial), Trapiá (Crateva } \\
\text { tapia), Ingá (inga spp) e Mulungú (Erythrina verna) }\end{array}$ \\
\hline
\end{tabular}

Fonte: Elaborado pelo autor (2019).

O mosaico de solos do estado do Ceará, além das vulnerabilidades impostas pela irregularidade pluviométrica do semiárido, parte significativa apresentam-se degradados, em função dos usos e pressões históricas as quais foram submetidos (CEARÁ, 2005). De mesmo modo, a caatinga, a mata seca e a mata ciliar passam por profundas transformações que intensifica os processos morfodinâmicos. O extrativismo vegetal indiscriminado, a pecuária extensiva, as práticas agrícolas rudimentares e os empreendimentos produtivos/capitalistas são os promotores da degradação desses recursos.

\section{Histórico de ocupação e aspectos socioeconômicos}

O processo de colonização do Ceará se deu tardiamente comparado às capitanias de Pernambuco e Bahia, isso pelo desconhecimento do território, pela resistência indígena e 
Aspectos geoambientais das áreas de nascentes no alto curso da sub-bacia hidrográfica do rio Figueiredo/Ceará

Diêgo Souza Albuquerque; Maria Losângela Martins de Sousa

pelos fatores naturais como as correntes marítimas (CHAVES, 2016). Quanto ao povoamento dos interiores cearenses, duas atividades merecem destaque: a pecuária e a cotonicultura.

Inicialmente, desenvolveu-se a pecuária quando o gado e seus tangedores adentraram o sertão, uma vez que essa cultura era proibida no litoral em detrimento do desenvolvimento da cultura da cana-de-açúcar. Esses animais eram comercializados em feiras pelas capitanias nordestinas, sendo levados a pé por longas distâncias entre os locais de comércio. Pelo esforço dispensado pelos animais, acabavam perdendo robustez e diminuindo seu preço na comercialização.

Com o objetivo de minimizar os prejuízos, a partir da segunda metade do século XVIII, o gado passou a ser abatido e transportado para os mercados consumidores mediante o processo de salga que conservava a carne bovina por mais tempo (CHAVES, 2016). Esse momento foi fundamental para a época, no qual as oficinas de charques foi uma importante atividade econômica no decorrer da colonização, bem como, foi responsável pela concentração de poder na região dos criadores de gado.

O adensamento do sertão foi propiciado pelo surgimento de alguns núcleos de povoamento próximos aos cursos de rios, formados pela influência das estradas das boiadas que promoviam a comunicação do Ceará colonial, ampliando as atividades comerciais e o povoamento da capitania (SILVA; ALENCAR, 2015).

Desse contexto de territorialização cearense, se desenvolveu a maioria das vilas do estado, correspondendo a unidades territoriais com relativa autonomia política e administrativa, sendo células originais que deram origem aos 184 municípios cearenses atuais (SILVA; ALENCAR, 2015). No período colonial foram estabelecidas 16 vilas, dentre elas, na região Jaguaribana: Icó posta em 1735 sendo a $3^{\text {a }}$ da capitania, Aracati criado em 1747 sendo a $4^{\mathrm{a}}$, e Russas em 1799, sendo a $12^{\mathrm{a}}$ vila implantada (SILVA; ALENCAR, 2015).

A atividade algodoeira desenvolvida no Ceará data do período colonial, vindo a ser intensificada no século XIX, momento em que o algodão passaria a ter valor no mercado externo (CHAVES, 2016). Essa atividade aconteceu de forma concomitante com a pecuária extensiva, possibilitando a permanência e intensificando o uso das potencialidades do sertão, organizando o espaço fundiário desigual e perverso, dado o notório estabelecimento dos grandes latifúndios em mãos dos mais abastados.

No enredo que se desenvolve o vale Jaguaribe, cabe sinalizar questões conflitais que se historicizaram. Estas demostram como se fez a ocupação histórica dessa região, na qual o recorte de pesquisa em tela está inserido. Dentre os conflitos podem ser registrados os 
Aspectos geoambientais das áreas de nascentes no alto curso da sub-bacia hidrográfica do rio Figueiredo/Ceará

Diêgo Souza Albuquerque; Maria Losângela Martins de Sousa

confrontos entre índios e colonizadores e o sistema escravocrata existente. Ambos momentos foram dolorosos para a história cearense.

Discutindo acerca dos indígenas e negros no vale do Jaguaribe, Ferreira Neto (2019) compreende que o processo de conquista do Nordeste se realizou graças ao extermínio dos naturais da terra e à desestruturação tribal. Em princípio, o autor afirma não existir um consenso acerca da quantidade de tribos indígenas que viviam no vale Jaguaribe, ficando algumas sem denominação precisa, a exemplo das tribos jaguaribaras, jaguaruanas, icós e icozinhos (presentes na região da serra do Pereiro). O que se sabe é a ocorrência de confrontos entre os nativos que desejavam defender as terras nas quais viviam e tinham como suas e os brancos coloniais imigrantes que desejavam civilizar novas áreas, tendo que, para isso, descaracterizar as populações então povoadas.

Primeiramente, o povoamento colonial se deu na ribeira do Jaguaribe, se intensificando no final do século XVII com a concessão de sesmarias e a progressiva formação de currais e fazendas rio acima, desassossegando os índios da região, o que promoveu inúmeros conflitos (FEREIRA NETO, 2019). O autor discute que o vale do Jaguaribe foi tomado das tribos indígenas entre 1680 a 1730. Isso provocou nos fazendeiros um sentimento de insegurança, intitulando os nativos de selvagens e cruéis. Essas concepções geraram conflitos, colocando em alvo a sobrevivência dos índios. Os índios mais arredios foram mortos em confrontos, alguns foram catequisados segundo a cultura ocidental e outros serviram aos colonizadores como escravos. A religiosidade, nesse momento, teve atuação fundamental, uma vez que funcionou com atenuante dos confrontos, aculturando o índio conforme costume europeu.

Quanto a mão de obra escrava negra no vale Jaguaribe, Ferreira Neto (2019) compreende que essa não se mostrou tão contundente quanto em outras partes do Nordeste. Isso se deu pelo fato do vale Jaguaribe não contar com atividades econômicas ligadas ao capital estrangeiro na época, culminando como uma "zona econômica secundária" que não necessitava de excedentes de mão de obra cativa, diferentemente do que ocorria na indústria açucareira na Zona da Mata e na cafeicultura na Paraíba.

Mesmo o processo produtivo inicial cearense - criatório e algodoeiro - não tendo a força escrava como determinante, não exclui o mesmo da atividade escravocrata. $\mathrm{O}$ vale do Jaguaribe, adotou a escravidão. O escravo jaguaribano, embora com um peso econômico inferior em comparação com o das áreas mais ricas, teve um importante papel no serviço doméstico, como trabalhador subsidiário e como obreiro qualificado. Ferreira Neto (2019) evidencia a presença de escravos em Pereiro: 


\section{CEARENSE, 10 DE SETEMBRO DE 1871}

No dia 14 do corrente mês, fugio o meu escravo Venceslão, de idade de 33 anos, mulato, baixo, gordo, pouca barba, nariz afilado, boca grande; tem falta do dedo mínimo em uma das mãos, pés regulares, tem uma cicatriz nas costas; é disfarçado, traiçoeiro e metido a valentão. É carpina, também entende de pedreiro e sapateiro. Rogo, portanto, as autoridades policiais ou a qualquer pessoa que encontrar dito escravo de o capturar, podendo entregar no Pereiro, na fazenda Trigueiro à sua senhora, em Baturité ao Sr. Tenente-coronel José Pacífico da Costa Caracas, e na capital ao Sr. José Martiniano Peixoto de Alencar, que será generosamente recompensado. Trigueiro, 15 de Agosto de 1871. Joaquim Rosa Botão (FERREIRA NETO, 2019, p. 24-25).

Na fazenda Trigueiro, atualmente, se encontra um ponto turístico/histórico do município de Pereiro, contendo um casarão antigo denominado de casa dos escravos. Casa dos escravos não por ter sido moradia destes, mas pelo fato de ter sido construído a partir do trabalho escravo, controlados pelo fazendeiro da época.

Ferreira Neto (2019) apresenta um levantamento da quantidade de escravos no vale Jaguaribe entre 1804 a 1883. O município de Pereiro, em 1860, possuía população escrava de 379 pessoas, em 1872 era de 504 cativos, 1873 de 528 escravos, 1881 eram 465 e em 1883, ano de libertação dos escravos no Ceará, 372 cativos.

Na seca de 1777 que se vivenciou no estado do Ceará, muitos civis se deslocaram entre o território. $\mathrm{O}$ atual território de Pereiro recebeu a chegada de inúmeras pessoas na época, que venheram se estabelecerem na serra devido as condições que a mesma oferecia. Considerando a história de municipalização cearense para o recorte de estudo, percebe-se que Pereiro, a partir do ano de 1890, teve importante influência na formação dos municípios de Ereré, Iracema e Potiretama, onde os limites do município primeiro cobriam a área atual dos secundários e a história destes é influenciada pela população e forças políticas de Pereiro.

O processo de territorialização e mercantilização cearense também influenciou na formação dos municípios na qual está localizado as áreas de nascentes em estudo. As atividades econômicas secundárias da pecuária e cotonicultura ainda guardam reflexos na área, possuindo estreita relação com as atividades produtivas da população atuantes do meio rural e com o quadro ambiental atual. Ferreira Neto (2003) observa que na região jaguaribana, a Serra de Pereiro disponha de condições favoráveis à produção de algodão, sendo Pereiro um grande produtor na província, e o produto gerado destinava-se a Aracati.

Como já explicitado, a área em estudo compreende territórios de Pereiro, Ereré e Iracema. Esses somam 37.719 habitantes, segundo IBGE (2019). Fato importante que deve ser evidenciado é o significativo número populacional que reside na zona rural no município de Pereiro, com um total de 10.32 habitantes, o que representa $65,52 \%$ da população total do 
Aspectos geoambientais das áreas de nascentes no alto curso da sub-bacia hidrográfica do rio Figueiredo/Ceará

Diêgo Souza Albuquerque; Maria Losângela Martins de Sousa

município. Dessa informação, auferir-se um constante uso da natureza, haja vista que a população rural utiliza do meio natural para desenvolver suas atividades produtivas.

Quanto as atividades econômicas nos municipios, destacam-se três: serviços, agropecuária e agroindústria. Os serviços representam o maior peso econômico, constituido pelo comércio e pelas atividades da Administração Pública (APU), como seguridade social, atendimentos em saúde, educação e infraestrutura nos municípios. Deste, Pereiro apresenta maior porcentagem, com 69,3\%. As atividades ligadas ao serviço são importantes para manter o ritmo de consumo dos municípios.

A agropecuária, exceto em Iracema, apresenta a segunda atividade desenvolvida. Tem maior expressão em Ereré, concebendo 25,5\% da economia local. Os originados desta atividade estão nas dinâmicas produtivas no meio rural, representada pelas diversas culturas da agricultura permanentes e temporárias e pelos negócios na pecuária.

Pereiro possui o maior número de estabelecimentos agropecuários, 1.620, demostrando uma divisão de terras mais efetiva, ou seja, cada estabelecimento possui em média 5,83 ha. Iracema possui 818 estabelecimentos distribuídos numa área maior, o que significa dizer que cada estabelecimento possui em média cerca de 62,55 ha. Isso comprova a existência de maiores latifúndios, haja vista esse município possuir a maior extensão territorial, comparado aos outros municípios, e que sua extensão está sob jurisprudência de 818 produtores, considerando a definição do estabelecimento agropecuário. Quanto a agroindústria, Iracema fica com maior expressão, enquanto que em Ereré pouco essa atividade influencia na manutenção econômica.

Em uma abordagem mais atual para o estado do Ceará, o IPECE (CEARÁ, 2019) lançou estudo realizado sobre o Produto Interno Bruto (PIB) municipal e sua contribuição para o PIB estadual. Mediante esse estudo, percebe-se que o município de Pereiro tem evoluindo em seu PIB, principalmente pela prestação de serviços.

Com relação ao PIB per capita (por pessoa), Pereiro evoluiu da $99^{\mathrm{a}}$ posição para a $9^{\mathrm{a}}$, de 2002 para 2017. Outro dado expressivo é a contribuição da prestação de serviços no PIB de Pereiro, sendo que em 2017 o apoio desse setor foi de 73,31\%. Em uma escala estadual, Pereiro figura como um dos municípios em que o serviço (exclui-se a APU) é o setor mais expressivo na economia local. Quanto aos serviços em Pereiro, nele está localizado a sede de uma grande empresa de Telecomunicações e a fábrica de uma empresa cearense de polpa de frutas. Essas empresas contribuem significativamente para a geração de empregos/serviços no município, o que repercute de forma positiva na economia local. 
Aspectos geoambientais das áreas de nascentes no alto curso da sub-bacia hidrográfica do rio Figueiredo/Ceará

Diêgo Souza Albuquerque; Maria Losângela Martins de Sousa

Em um comparativo entre os municípios do Ceará em 2017, Ereré apresenta um dos menores PIB, com apenas $0,04 \%$. Nesse município o maior contribuinte do seu PIB foi o setor da Administração Pública, seguindo pelas atividades da agropecuária (CEARÁ, 2019). Para o município de Iracema, os principais contribuintes de seu PIB são os mesmos de Ereré.

\section{Considerações finais}

O levantamento dos elementos apontados constitui-se em uma gama de fatores que influenciam na diversidade paisagística da área, sendo essa constituída de atributos naturais e efeitos das construções sociais. A análise dos elementos do meio físico desse recorte permite afirmar que essa área possui potencial para as atividades de pecuária, agricultura de subsistência, extração de lenha como matriz energética, extração de solos para construção civil, potencial para fruticultura e riqueza paisagística para atividades de eco e geoturismo.

A análise da ocupação aponta que os recursos naturais são historicamente utilizados com vista a desenvolver as atividades de bases para sobrevivência da sociedade local. Essas atividades refletem de forma concisa na degradação dos recursos naturais, necessitando ações mais sustentáveis para o uso dos mesmos. Tais mudanças se vinculam ao histórico "civilizatório" dos sertões do território cearense e do vale Jaguaribe, tendo a pecuária como elementar vetor de ocupação.

Por fim, as compreensões dos elementos em tela são essenciais para a análise sistêmica, e mediante esta subsidiar reflexões mais profundas ao conhecimento da área e, consequentemente, podendo ser geradas diretrizes que possam auxiliar na tomada de decisões sobre o uso dos elementos naturais e desenvolvimnto de ações sustentáveis.

\section{Referências}

BOTELHO, R. G. M. Planejamento Ambiental em microbacia hidrográfica. In: GUERRA, A. J. T; SILVA, A. S.; BOTELHO, R. G. M. (org.). Erosão e Conservação dos solos: Conceitos, temas e aplicações. Rio de Janeiro: Bertrand Brasil, 1999 p. 269-295.

BRASIL. Lei no 12.651, de 25 de maio de 2012. Disponível em: <http://www.planalto.gov.br/ccivil_03/_ato2011-2014/2012/lei/L12651compilado.htm>. Acesso em: 12 mai. 2019.

CEARÁ. Produto Interno Bruto Municipal: Análise do PIB dos Municípios Cearenses2002, 2010, 2016 e 2017. SPG/IPECE, Fortaleza, 2019. Disponível em: <https://www.ipece.ce.gov.br/wpcontent/uploads/sites/45/2019/12/PIB_dos_Municipios_Cear enses_2002_2017.pdf>. Acesso em: 18 mai. 2020.

Ceará em Mapas - Tipos Climáticos. Fortaleza, 2007. 
Aspectos geoambientais das áreas de nascentes no alto curso da sub-bacia hidrográfica do rio Figueiredo/Ceará

Diêgo Souza Albuquerque; Maria Losângela Martins de Sousa

Programa Nacional de Combate à Desertificação. Panorama da desertificação no estado do Ceará. Fortaleza/CE, 2005.

Mapa Exploratório - Reconhecimento de solos do Estado do Ceará. 1972.

CHAVES, L. A. História do Ceará. Sobral/CE: INTA, 2016.

CPRM. Companhia de Pesquisa de Recursos Minerais. Mapa Geodiversidade do Estado do Ceará. 2014.

Mapa Geológico do Estado do Ceará. 2003.

EMBRAPA. Empresa Brasileira de Pesquisa Agropecuária. Sistema Brasileiro de Classificação de Solos. 5. ed., rev. e ampl. Brasília/DF: Embrapa, 2018.

. Solos do Nordeste. Recife: Embrapa Solos, 2015.

FERNANDES, A. Fitogeografia brasileira: fundamentos fitogeográficos. $1^{\mathrm{a}}$ parte. $2^{\mathrm{a}}$ ed. Fortaleza/CE: Edições UFC, 2006.

FERREIRA NETO, C. Indígenas e negros no Vale do Jaguaribe: entre o cativeiro e a liberdade. Disponível em: <https://apeoc.org.br/wp-content/uploads/2018/08/Indigenas_e _Negros_no_Vale_Jaguaribe.pdf $>$. Acesso em: 30 jan. 2019.

Estudos de História Jaguaribana: documentos, notas e ensaios diversos para história do Baixo e Médio Jaguaribe. Fortaleza: Premius, 2003.

FUNCEME. Fundação Cearense de Meteorologia e Recurso Hídrico. Ceará passa pela pior seca prolongada desde 1910. 2016.

IBGE. Instituto Brasileiro de Geografia e Estatística. População estimada municipal - 2019. IBGE Cidades, 2019. Disponível em: 〈https://cidades.ibge.gov.br/brasil/ce/panorama> . Acesso em: 19 mai. 2020.

Manual técnico de geologia. Departamento de Recursos Naturais e Estudos Ambientais. Rio de Janeiro: IBGE, 1998.

IPECE. Instituto de Pesquisa e Estratégia Econômica do Ceará. Classes de Solos. Disponível em: 〈http://www2.ipece.ce.gov.br/atlas/capitulo1/12/pdf/1.2.4_classes_de_solos.Pdf $>$. Acesso em: 22 mar. 2020.

MAIA, R. P.; BEZERRA, F. H. R. Condicionamento Estrutural do Relevo no Nordeste Setentrional Brasileiro. Mercator, Fortaleza, v. 13, n. 1, p. 127-141, jan./abr. 2014. Disponível em: <https://www.scielo.br/pdf/mercator/v13n1/1676-8329-mercator-13-010127.pdf>. Acesso em: 8 jun. 2019.

NUNES, E. Geografia física do Rio Grande do Norte. 1ª . Natal: Ed. Natal, 2006.

ROSS, J. Geomorfologia: ambiente e planejamento. São Paulo: Contexto, 2012. 
Aspectos geoambientais das áreas de nascentes no alto curso da sub-bacia hidrográfica do rio Figueiredo/Ceará

Diêgo Souza Albuquerque; Maria Losângela Martins de Sousa

SANT'ANNA NETO, J. L. Clima e organização do espaço. Boletim de Geografia, Maringá, v. 16, n. 1, p. 119-131, 1998. Disponível em: <http://www.periodicos.uem.br/ojs/index.php/BolGeogr/article/view/12158/7322>. Acesso em: 6 ago. 2019.

SILVA, V.; ALENCAR, F. A, G. Formação territorial do Ceará: das 16 vilas originais aos 184 municípios atuais. Boletim Goiano de Geografia, v. 35, n. 1, jan-abr. p. 53-69, 2015. Disponível em: <http://www.redalyc.org/articulo.oa? id=337138459005>. Acesso em: 21 mai. 2019.

SOUSA, M. L. M. Diagnóstico geoambiental da sub-bacia hidrográfica do rio Figueiredo, Ceará: subsídios ao planejamento ambiental. Dissertação de Mestrado apresentado Programa de Pós-Graduação em Geografia/Universidade Federal do Ceará, 2012. 144f.

SOUZA, M. J. N. Contribuição ao estudo das unidades morfoestruturais do estado do Ceará. Revista de Geologia, n. 1, v. 1, 1988.

SOUZA, M. J. N.; OLIVEIRA, V. P. V. Análise ambiental - uma prática da interdisciplinaridade no ensino e na pesquisa. REDE - Revista Eletrônica do Prodema, Fortaleza, v. 7, n. 2, nov. 2011. Disponível em: <http://www.revistarede.ufc.br/rede/article/view/168 >. Acesso em: 18 mar. 2019.

VIEIRA, P. P. B.; GONDIM FILHO, J. G. C. Água Doce no Semiárido. In: REBOLÇAS, A. C.; BRAGA.; TUNDISI, J. G. Águas Doces no Brasil: Capital Ecológico, Uso e Conservação. $3^{\text {a }}$ ed. São Paulo: Escrituras, 2002, p. 481-504. 